\title{
BMJ A trans European Union difference in open the decline in trans fatty acids in popular foods: a market basket investigation
}

\author{
Steen Stender, ${ }^{1}$ Arne Astrup, ${ }^{2}$ Jørn Dyerberg ${ }^{1}$
}

To cite: Stender S, Astrup A, Dyerberg J. A trans European Union difference in the decline in trans fatty acids in popular foods: a market basket investigation. BMJ Open 2012;2:e000859. doi:10.1136/bmjopen-2012000859

- Prepublication history for this paper are available online. To view these files please visit the journal online (http://dx.doi.org/10.1136/ bmjopen-2012-000859).

Received 23 May 2012 Accepted 31 July 2012

This final article is available for use under the terms of the Creative Commons Attribution Non-Commercial 2.0 Licence; see http://bmjopen.bmj.com

${ }^{1}$ Department of Clinical Biochemistry, Copenhagen University Hospital, Gentofte, Denmark

${ }^{2}$ Department of Human Nutrition, University of Copenhagen, Copenhagen, Denmark

Correspondence to Dr Steen Stender; stst@geh.regionh.dk

\section{ABSTRACT}

Objectives: To minimise the intake of industrial trans fatty acids (I-TFA) some countries have introduced labelling, while others have introduced legislative limits on the content of I-TFA in food. However, most countries still rely on food producers to voluntarily reduce the I-TFA content in food. The objective of the present study was to investigate the efficiency of these strategies in the EU.

Design: The potential consumption of I-TFA was assessed in a market basket investigation by analysing the I-TFA content in popular foods.

Setting: A standardised purchase methodology was used in 16 EU countries in 2005 and again in 2009.

Samples: Seventy servings of French fries and chicken nuggets, 90 packages of microwave popcorn, and 442 samples of biscuits/cakes/wafers with 'partially hydrogenated vegetable fat' listed high on the list of ingredients were analysed. A high-trans menu was defined as a large serving of French fries and nuggets, $100 \mathrm{~g}$ of microwave popcorn and $100 \mathrm{~g}$ of biscuits/wafers/cakes.

Results: In 2005, a high-trans menu provided above $30 \mathrm{~g}$ of I-TFA in five EU countries in Eastern Europe and 20-30 g in eight EU countries in Western Europe. In 2009 the values in Hungary, Poland and the Czech Republic remained high between 10 and $20 \mathrm{~g}$, whereas they were less than $2 \mathrm{~g}$ in Germany, France and the UK.

Conclusions: In 2009 contents of I-TFA in popular foods in Western Europe appear low but, in spite of some reduction, still high in Eastern European EU countries. These findings suggest that millions of people in the EU still consume I-TFA in amounts that substantially increase their risk of coronary heart disease.

\section{INTRODUCTION}

Trans fatty acids (TFA) in food originate from industrial hydrogenation of oils and from ruminant sources. Compared to unhydrogenated oils, fats containing industrial TFA (I-TFA) are solid at room temperature, have some technical advantages in food processing, and prolong the shelf life of food. However I-TFA can constitute up to $60 \%$ of the fats in

\section{ARTICLE SUMMARY}

Article focus

- Are popular foods with high amounts of industrial trans fatty acids (TFA) still available in EU countries in 2009 to the same extent as it was in 2005.

- Is there a difference in availability of such foods between Western and Eastern EU countries.

Key messages

- Industrial TFA in popular foods in Western EU countries have declined considerably since 2005.In Eastern Europe industrial TFA in some popular foods are in spite of some decline still high.

- A low-average intake of industrial TFA at the population level does not preclude a high intake among subgroups.

- Most EU countries rely on food producers to voluntarily reduce the amounts of industrial TFA in foods with variable results. An effective alternative is legislation so far only used by a few EU countries.

Strengths and limitations of this study

- A strength is the measurement of TFA in many popular foods in several EU countries in 2005 and again in 2009.

- A limitation is that the average daily intake of TFA was not measured in subgroups of the population, but instead inferred from the popularity of fast food and from the presence of popular foods with high amounts of industrial TFA in large supermarkets.

certain foods, whereas ruminant fat contains at most $6 \%$ TFA. $^{1}$ A meta-analysis of four large prospective studies found that an intake of TFA corresponding to $2 \%$ of the total energy intake (E\%) (approximately $5 \mathrm{~g}$ /day) was associated with a $23 \%$ increase in the risk of coronary heart disease. ${ }^{2}$ Several public health organisations have recommended that I-TFA intake should be lowered as much as possible. ${ }^{3-5}$ In 1976, the average intake of TFA in Western Europe was $6 \mathrm{~g}$ /day. In 1996, this intake had dropped to $2.6 \mathrm{~g}$ /day (range 1.2 $6.7 \mathrm{~g} /$ day), corresponding to $0.5-2.1 \mathrm{E} \%{ }^{6}$ 
Approximately half of this intake was from ruminant TFA and only about $1.3 \mathrm{~g}$ was from I-TFA, which constitutes a $78 \%$ decrease since $1976 .{ }^{6}$ Despite a mean population intake of approximately $1 \mathrm{~g}$ of I-TFA per day in Denmark in 2001, it was still possible to consume 20-30 $\mathrm{g}$ of I-TFA in a single high-trans menu by eating popular food products such as wafers, microwave popcorn, nuggets and French fries. ${ }^{5}$ Among the 5 million Danes, $10000-50000$ people consumed food from this type of menu several times each week, and got a daily intake of more than $5 \mathrm{~g} \mathrm{I-TFA.}{ }^{5}$ Generalising to the population in the EU, this corresponds to 1-5 million people.

In 2003, Canada introduced the mandatory labelling of the I-TFA content in pre-packaged food. In the same year, Denmark introduced a legislative limit of $2 \%$ I-TFA in fat used for foods. The EC initially opposed this legislation but in March 2007 dropped its infringement proceedings against Denmark because of increased scientific evidence on the dangers of trans fats. ${ }^{7}$ The USA introduced mandatory labelling of prepackaged food in 2006, followed by legislative limits on I-TFA in the food served in restaurants in New York City in 2008 and in 2010-2011 in the state of California. In 2009, Austria and Switzerland and in 2011 Iceland introduced a legislative ban similar to the Danish' to be followed also by Sweden. It means that in 2012 only a minority, that is, approximately 14 million people of the 500 million people in EU are protected by legislation against foods with high amounts of I-TFA.

In 2005, we assessed by a market basket investigation the availability of a high-trans menu (large servings of French fries and nuggets, $100 \mathrm{~g}$ of microwave popcorn and $100 \mathrm{~g}$ of biscuits/wafers/cakes) in $15 \mathrm{EU}$ countries, and found that, in spite of a low mean intake, high concentrations of I-TFA were still present in many popular foods. Thus, subgroups of the populations could have an intake that is considerably higher than the recommended upper limit for intake of I-TFA. ${ }^{8}$ I-TFA in foods from international fast food providers was an important contributor to the high intake in these subpopulations. ${ }^{9}$ Still in 2009, EU countries (with the exception of Austria and Denmark) rely on food producers to voluntarily reduce the amounts of I-TFA in foods. The present study assesses the efficiency of that strategy in three Eastern European countries, Hungary, Poland and the Czech Republic, and in three Western European countries, Germany, France and the UK.

\section{METHODS}

\section{Purchase of food products}

Between November 2004 and January 2006, 542 items of foods were purchased in 26 countries. The cities included were partly determined by visits taken by the authors and their colleagues for other purposes, and these visits were supplemented by arranged visits by two of the authors (SS and JD). The tourist office in the city was asked to identify three large supermarkets in the vicinity, preferably chain supermarkets with many large shops in the capital and across the country. A written procedure was followed that included details about which products to select and instructions for storage methods until the food could be returned to the laboratory. Fast-food items (chicken nuggets and French fries) were obtained from McDonald's and KFC outlets. Microwave oven popcorn and biscuits/cakes/wafers were bought if 'partially hydrogenated fat' or a similar term was listed among the first three ingredients and if the food label indicated that the fat content exceeded $15 \mathrm{~g}$ of fat per $100 \mathrm{~g}$.

In July 2009 to September 2009, the capitals of Poland, the Czech Republic, Hungary, Germany, France and the UK were revisited and the same procedures for the purchase of food items were followed. If possible, the same stores were revisited and the same brands were bought. Altogether, 602 samples of food in EU countries were purchased.

\section{Analysis for TFA}

The microwave popcorn was popped before processing. The foods were homogenised, and the fatty acid content was analysed by gas chromatography (GC) on a $100 \mathrm{~m}$ highly polar capillary column. Thin layer chromatography on silver nitrate-impregnated silica with renewed GC verified the results. ${ }^{10}$ The method is accredited by the Danish Accreditation Authorities (DANAK) according to ISO 17025.

\section{Calculation}

For comparison, the amounts of I-TFA in the French fries and the chicken nuggets were expressed as the amounts in a serving size equivalent to a large serving from McDonald's in the USA. The serving sizes were $171 \mathrm{~g}$ of French fries and $160 \mathrm{~g}$ of chicken nuggets.

The potential consumption of I-TFA in a given country was defined as the sum of the I-TFA contents provided by a high-trans menu that consisted of products with the highest identified amount of I-TFA.

\section{RESULTS}

\section{Biscuits, cakes and wafers}

Figure 1 presents data from the products bought in the six EU countries in 2005 and 2009. The products are ranked according to I-TFA content and the combined values for the three Eastern EU countries and for the three Western EU countries are given separately. The highest I-TFA contents (10-15 g) in single $100 \mathrm{~g}$ servings in 2005 were found in Hungary, Poland and the Czech Republic. In France, Germany and the UK, the I-TFA contents were lower but still with many above $2 \mathrm{~g}$ in $100 \mathrm{~g}$ product.

In 2009, biscuits, cakes and wafers in the three Eastern EU countries contained a smaller, but still substantial, amount of I-TFA. In contrast, the I-TFA content in products in the three Western EU countries was minimal $(<1 \mathrm{~g})$. The same pattern was observed in each of the countries. 

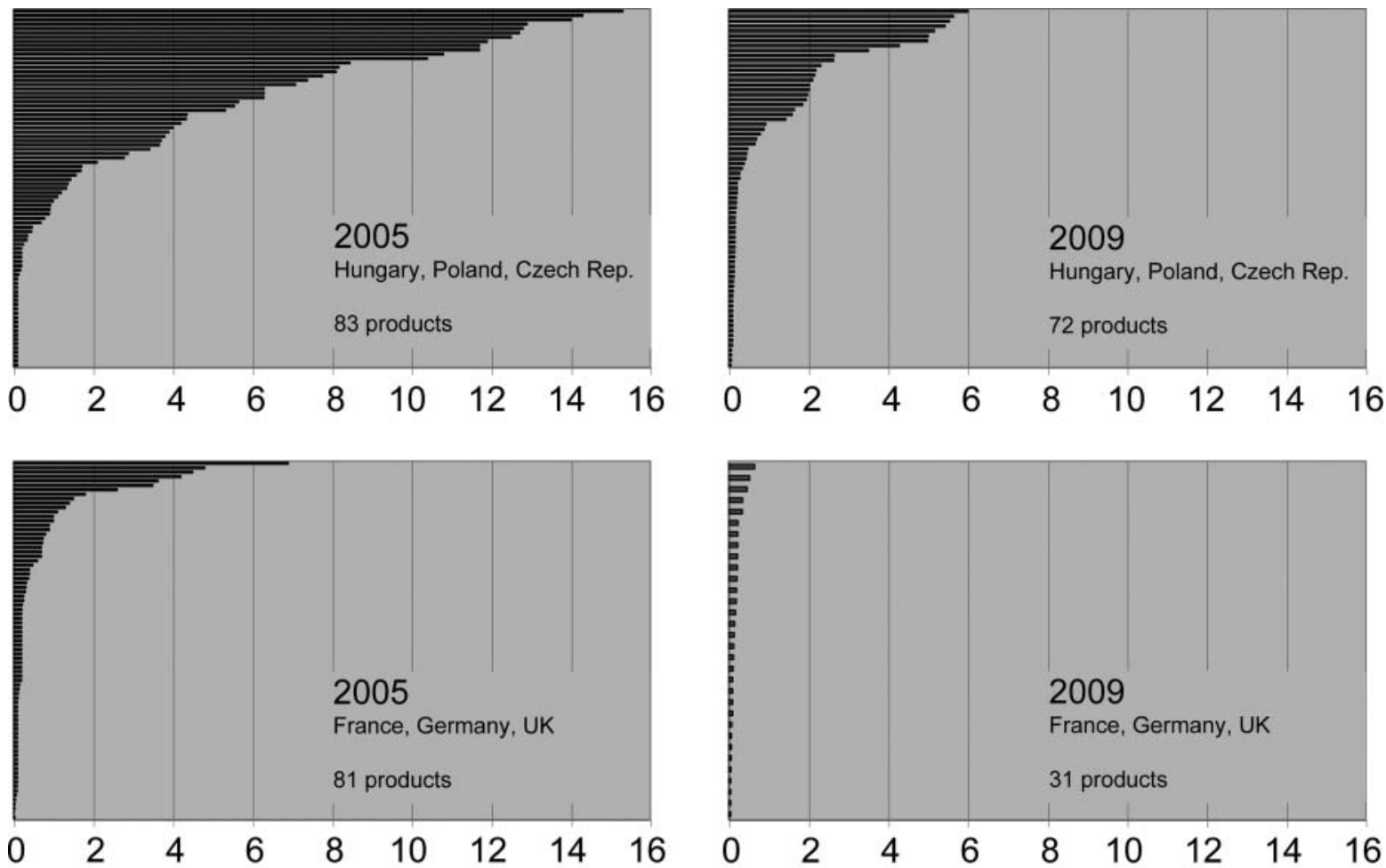

\section{Grams of industrial trans fatty acids in $100 \mathrm{~g}$ of product}

Figure 1 Amounts of industrial trans fatty acids (TFA) in $100 \mathrm{~g}$ of biscuits/cakes/wafers bought in six EU countries in 2005 and in 2009. For both groups of countries (three Eastern EU countries and three Western EU countries), the products are ranked according to the concentrations of industrially produced TFA. Products were only bought if 'partially hydrogenated fat' or a similar term was listed among the first three ingredients and if the food label indicated that the fat content exceeded $15 \mathrm{~g}$ of fat per $100 \mathrm{~g}$. Fewer products in Western EU countries fulfilled the inclusion criteria compared with products in Eastern EU countries.

Only in few cases was the same brand of biscuits, cakes and wafers from the 2005 purchase included in the 2009 purchase either because it had disappeared from the shop or because it did no longer have the term partially hydrogenated fat on the list of ingredients. When the same brand was included in the purchases the amount of I-TFA in that brand has declined from 2005 to 2009 , but other brands with higher amounts have appeared on the shelves.

The values in figure 1 are given in table 1 for each food item from each country.

\section{Fast food}

In 2005, the I-TFA content of the McDonald's servings in EU varied from less than $1 \mathrm{~g}$ in Copenhagen to $7 \mathrm{~g}$ in London, UK. For KFC servings, there were even larger differences between the countries, ranging from less than $1 \mathrm{~g}$ in Germany to $24 \mathrm{~g}$ in Hungary. Only $15 \%$ of the 54 fast food servings contained more than $10 \mathrm{~g}$ per serving, and $50 \%$ contained between 5 and $10 \mathrm{~g}^{9}{ }^{9}$

In 2009, each of the 12 fast food menus, which were collected in France, Germany and the UK in the same locations as in 2005, contained less than $1 \mathrm{~g}$ of I-TFA per serving (figures 2 and 3).

\section{Popcorn}

The highest I-TFA content in a single $100 \mathrm{~g}$ serving of microwave oven popcorn bought in each country is presented in the data given for the I-TFA content in the high-trans menu for that country (figure 2 and table 2).

In 2009, the microwave oven popcorn samples with the highest amounts of I-TFA, which were from Hungary, Poland and the Czech Republic, contained the same amounts of I-TFA as the popcorn that we analysed in 2005. In contrast, the I-TFA in popcorn from Germany, France and the UK was negligible (figure 3 and table 3).

The brand of microwave oven popcorn with the highest concentration of I-TFA (11.6 g I-TFA per $100 \mathrm{~g}$ product) found in the Czech Republic in 2005 did not contain I-TFA in 2009. However, the same brand had the highest concentration ( $7.6 \mathrm{~g}$ I-TFA per $100 \mathrm{~g}$ product) among the microwave oven popcorn bought in Hungary in 2009 (table 3).

\section{A high-trans menu}

In 2001, the potential consumption of I-TFA by eating a high-trans menu was $37 \mathrm{~g}$ in Denmark, but by 2005, this potential consumption level was reduced to less than $1 \mathrm{~g}$ (figure 2). In 2005, in contrast, the potential 
Table 1 Trans fatty acids (TFA) in biscuits, cakes and wafers bought in 2005 and 2009 in large supermarkets in the capital of the country

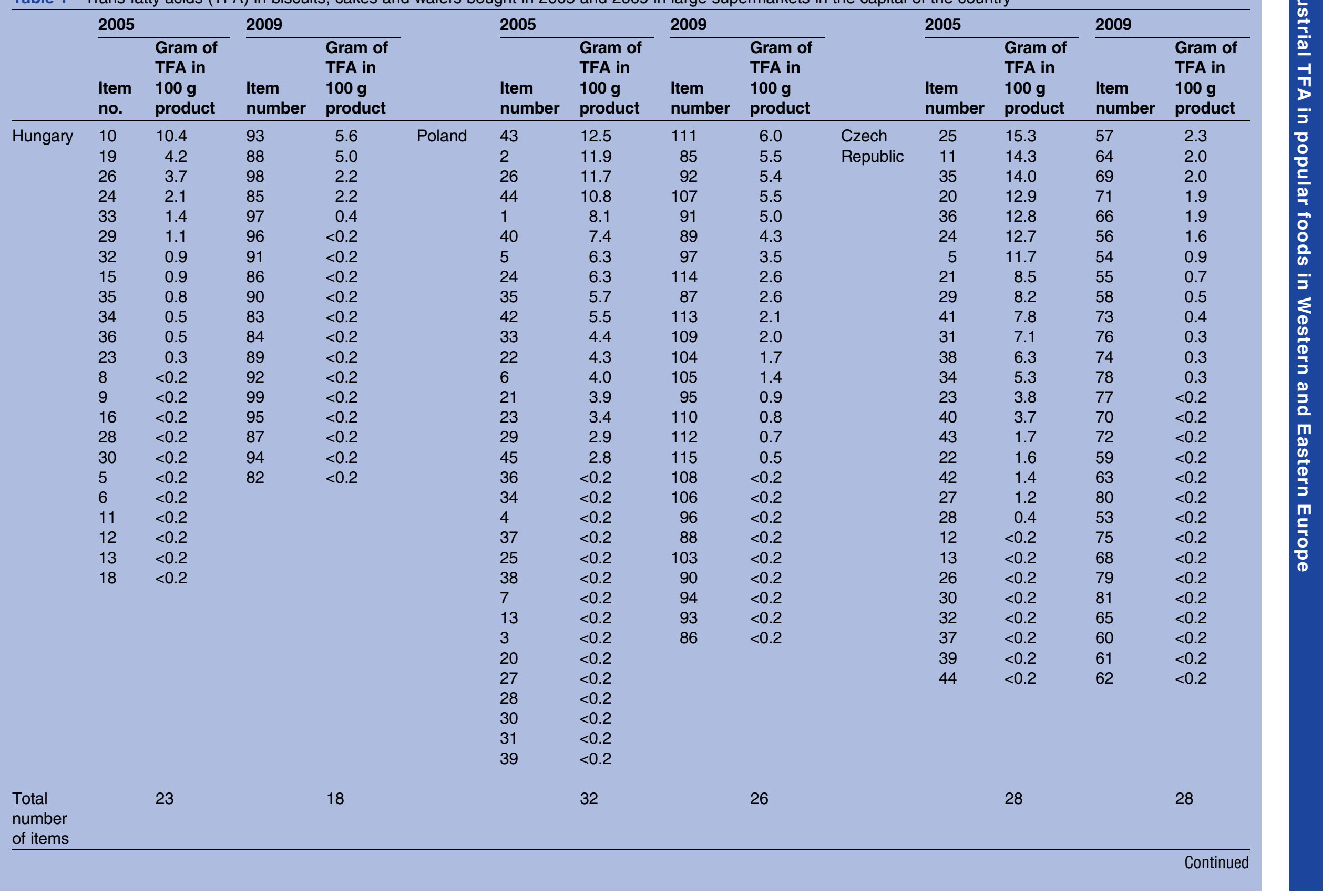




\begin{tabular}{|c|c|c|c|c|c|c|c|c|c|c|c|c|c|c|}
\hline & \multicolumn{2}{|l|}{2005} & \multicolumn{2}{|l|}{2009} & & \multicolumn{2}{|l|}{2005} & \multicolumn{2}{|l|}{2009} & & \multicolumn{2}{|l|}{2005} & \multicolumn{2}{|l|}{2009} \\
\hline & $\begin{array}{l}\text { Item } \\
\text { no. }\end{array}$ & $\begin{array}{l}\text { Gram of } \\
\text { TFA in } \\
100 \mathrm{~g} \\
\text { product }\end{array}$ & $\begin{array}{l}\text { Item } \\
\text { number }\end{array}$ & $\begin{array}{l}\text { Gram of } \\
\text { TFA in } \\
100 \mathrm{~g} \\
\text { product }\end{array}$ & & $\begin{array}{l}\text { Item } \\
\text { number }\end{array}$ & $\begin{array}{l}\text { Gram of } \\
\text { TFA in } \\
100 \mathrm{~g} \\
\text { product }\end{array}$ & $\begin{array}{l}\text { Item } \\
\text { number }\end{array}$ & $\begin{array}{l}\text { Gram of } \\
\text { TFA in } \\
100 \mathrm{~g} \\
\text { product }\end{array}$ & & $\begin{array}{l}\text { Item } \\
\text { number }\end{array}$ & $\begin{array}{l}\text { Gram of } \\
\text { TFA in } \\
100 \mathrm{~g} \\
\text { product }\end{array}$ & $\begin{array}{l}\text { Item } \\
\text { number }\end{array}$ & $\begin{array}{l}\text { Gram of } \\
\text { TFA in } \\
100 \mathrm{~g} \\
\text { product }\end{array}$ \\
\hline \multirow[t]{32}{*}{ France } & $1 b$ & 4.8 & 12 & 0.7 & Germany & $8 b$ & 6.9 & 42 & 0.3 & UK & $28 a$ & 4.5 & 58 & 0.2 \\
\hline & $22 a$ & 4.2 & 20 & 0.5 & & $17 \mathrm{~b}$ & 2.6 & 51 & $<0.2$ & & $4 a$ & 1.3 & 52 & 0.2 \\
\hline & $24 a$ & 3.6 & 13 & 0.5 & & $4 a$ & 1.4 & 43 & $<0.2$ & & $16 a$ & 1.0 & 56 & $<0.2$ \\
\hline & $4 a$ & 3.5 & 15 & 0.3 & & $13 a$ & 11 & 40 & $<0.2$ & & $17 a$ & 1.0 & 54 & $<0.2$ \\
\hline & $2 a$ & 1.8 & 16 & 0.2 & & $4 b$ & 0.8 & 41 & $<0.2$ & & $15 a$ & 0.9 & 51 & $<0.2$ \\
\hline & $26 a$ & 1.5 & 17 & 0.2 & & $3 a$ & 0.6 & 50 & $<0.2$ & & $36 a$ & 0.9 & 57 & $<0.2$ \\
\hline & $13 a$ & 0.7 & 21 & $<0.2$ & & $13 b$ & 0.4 & 46 & $<0.2$ & & $7 b$ & 0.7 & 55 & $<0.2$ \\
\hline & $3 a$ & 0.7 & 19 & $<0.2$ & & $5 a$ & 0.3 & 48 & $<0.2$ & & $2 b$ & 0.7 & 53 & $<0.2$ \\
\hline & $3 b$ & 0.7 & 22 & $<0.2$ & & $12 b$ & 0.3 & 44 & $<0.2$ & & $10 a$ & 0.4 & & \\
\hline & $15 a$ & 0.5 & 23 & $<0.2$ & & $8 a$ & $<0.2$ & 47 & $<0.2$ & & $33 a$ & 0.4 & & \\
\hline & $12 a$ & 0.3 & 18 & $<0.2$ & & $15 a$ & $<0.2$ & 49 & $<0.2$ & & $32 a$ & 0.3 & & \\
\hline & $5 a$ & $<0.2$ & 14 & $<0.2$ & & $1 b$ & $<0.2$ & & & & $34 a$ & 0.3 & & \\
\hline & $18 a$ & $<0.2$ & & & & $3 b$ & $<0.2$ & & & & $3 b$ & 0.2 & & \\
\hline & $2 b$ & $<0.2$ & & & & $16 b$ & $<0.2$ & & & & $31 a$ & $<0.2$ & & \\
\hline & $3 c$ & $<0.2$ & & & & $6 a$ & $<0.2$ & & & & $13 a$ & $<0.2$ & & \\
\hline & $17 a$ & $<0.2$ & & & & $7 a$ & $<0.2$ & & & & $1 a$ & $<0.2$ & & \\
\hline & $23 a$ & $<0.2$ & & & & $14 a$ & $<0.2$ & & & & $39 a$ & $<0.2$ & & \\
\hline & $1 \mathrm{a}$ & $<0.2$ & & & & $17 a$ & $<0.2$ & & & & $5 b$ & $<0.2$ & & \\
\hline & $16 a$ & $<0.2$ & & & & $6 b$ & $<0.2$ & & & & $6 b$ & $<0.2$ & & \\
\hline & $21 a$ & $<0.2$ & & & & $21 b$ & $<0.2$ & & & & $8 b$ & $<0.2$ & & \\
\hline & $25 a$ & $<0.2$ & & & & $16 a$ & $<0.2$ & & & & $9 b$ & $<0.2$ & & \\
\hline & $2 c$ & $<0.2$ & & & & & & & & & $29 a$ & $<0.2$ & & \\
\hline & $20 a$ & $<0.2$ & & & & & & & & & $23 a$ & $<0.2$ & & \\
\hline & $14 a$ & $<0.2$ & & & & & & & & & $11 a$ & $<0.2$ & & \\
\hline & $19 a$ & $<0.2$ & & & & & & & & & $12 a$ & $<0.2$ & & \\
\hline & $1 c$ & $<0.2$ & & & & & & & & & $2 a$ & $<0.2$ & & \\
\hline & $4 b$ & $<0.2$ & & & & & & & & & $38 a$ & $<0.2$ & & \\
\hline & & & & & & & & & & & $40 a$ & $<0.2$ & & \\
\hline & & & & & & & & & & & $4 b$ & $<0.2$ & & \\
\hline & & & & & & & & & & & $5 a$ & $<0.2$ & & \\
\hline & & & & & & & & & & & $8 a$ & $<0.2$ & & \\
\hline & & & & & & & & & & & $35 a$ & $<0.2$ & & \\
\hline $\begin{array}{l}\text { Total } \\
\text { number } \\
\text { of items }\end{array}$ & & 27 & & 12 & & & 21 & & 11 & & & 33 & & 8 \\
\hline
\end{tabular}


Figure 2 Amounts of industrial trans fatty acids (TFA) in a high-trans menu bought in various countries in 2005 . For each country, the product with the highest concentration of industrial TFA in each of the three food categories is shown.

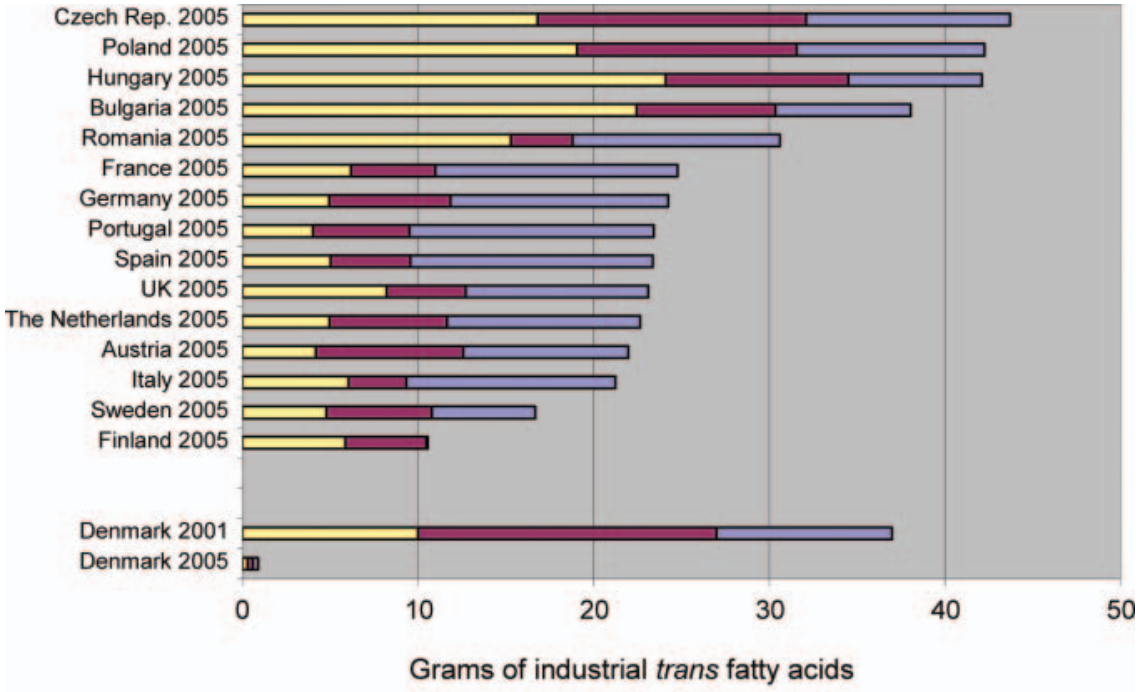

$\square$ A large serving of nuggets and French fries

$100 \mathrm{~g}$ biscuits/cakes/wafers

$100 \mathrm{~g}$ microwave popcorn consumption level via a high-trans menu exceeded $20 \mathrm{~g}$ in 13 of the 16 EU countries, from which foods were investigated. Hungary, the Czech Republic and Poland ranked among the highest, with values around $40 \mathrm{~g}$ per menu. A considerable amount of the I-TFA in the menus was derived from the fast-food meal.

Figure 3 demonstrates the time trends for I-TFA in the high-trans menu in Hungary, the Czech Republic, Poland, Germany, France and the UK. In all the countries, the contribution values obtained from McDonald's and KFC meals (nuggets and fries) in 2009 were negligible compared to the values obtained in 2005 .

In 2009, biscuits, cakes, wafers and microwave oven popcorn were still high in I-TFA in Eastern EU countries. In contrast, only small amounts of I-TFA in these same products obtained in Western EU countries were found.

\section{DISCUSSION}

The data from 2005 show that, despite a mean daily intake of around $1 \mathrm{~g}$ I-TFA for the entire population (as it was in Denmark in 2001), it was still possible to consume 30-40 g I-TFA in a high-trans menu composed of popular foods. Consequently, a low-average intake at the population level does not preclude a very high intake among some subgroups. ${ }^{8}$ Following Denmark's 2003 legislation, the I-TFA content of the same menu was reduced to less than $1 \mathrm{~g} .{ }^{9}{ }^{10}$ In addition, the data demonstrate that in 2005 it was possible to eat a menu of popular foods with more than $20 \mathrm{~g}$ of I-TFA in 13 of $16 \mathrm{EU}$ countries and up to $40 \mathrm{~g}$ in Hungary (figure 2). So far, EU countries (with the exception of Austria and Denmark) rely on food producers to voluntarily reduce the amounts of I-TFA in foods. The present study demonstrates the difference between Eastern and Western Europe in the efficiency of this strategy. The overall picture regarding the I-TFA content in fast food, biscuit/wafers/cookies and microwave oven popcorn in the EU indicates that I-TFA has disappeared from American-based fast food, such as that from McDonald's and KFC, mainly due to societal pressure. ${ }^{9} 11$ The same decline for biscuits and snacks in Western EU countries were observed. In Eastern EU countries, however, the amount of I-TFA in these products is still high. We even observed this difference in products bought at the same retailers in the Eastern and Western EU countries (eg, Carrefour).

\section{Limitations of the study}

The average daily intake of I-TFA was not measured in subgroups of the population, but instead inferred from the popularity of fast food from McDonald's and KFC and from the presence of popular foods with high amounts of I-TFA in large supermarkets. The assumptions are: (1) the analysed brands of biscuits, cakes, wafers and microwave oven popcorn were stocked at the supermarkets because they are sold in considerable amounts; (2) the majority of these foods are regularly bought and consumed by the same subgroups of consumers and (3) the findings in the supermarkets in each capital are representative of the entire country and of adjacent countries in the Eastern and Western Europe.

Another weakness is that only foods were bought in large supermarkets and from two international fast food providers (McDonald's and KFG). The I-TFA content in foods sold by small, privately owned shops or street vendors was not examined. Fats with high amounts of 
Figure 3 Time trends for the amounts of industrial trans fatty acids in a high-trans menu bought in three Eastern EU countries in 2005 and 2009 and in three Western EU countries in 2005 and 2009.
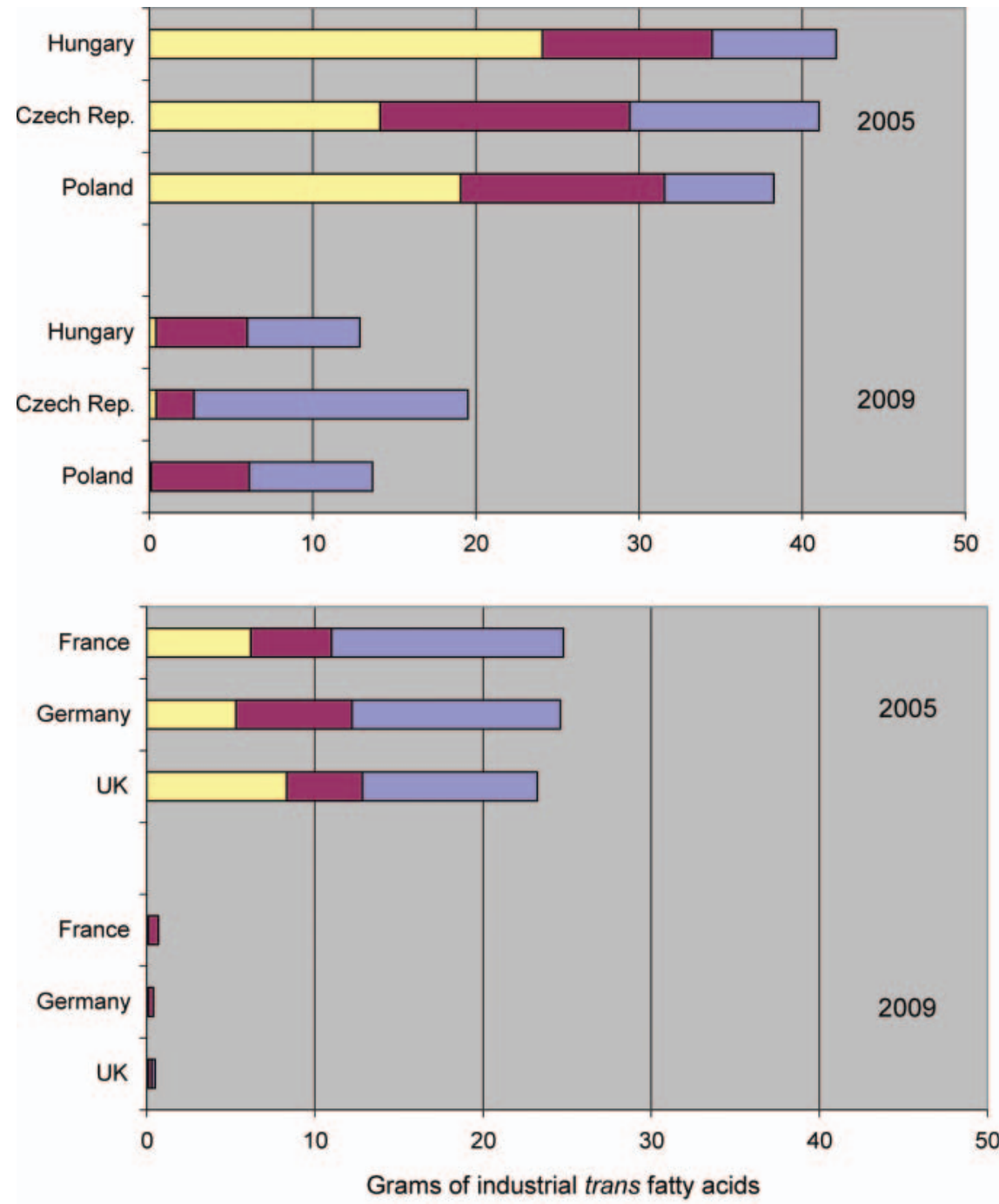

$\square$ A large serving of nuggets and French fries

$100 \mathrm{~g}$ biscuits/cakes/wafers

$100 \mathrm{~g}$ microwave popcorn
I-TFA prolong the shelf life of foods, and it is reasonable to assume that this factor is of even higher importance for small, privately owned shops than it is for larger supermarkets. The selective pattern of purchasing may thus have led to an underestimation of the amounts of I-TFA consumed by subgroups of the population.

\section{Implications}

An intake of above $5 \mathrm{~g}$ of TFA daily is associated with a health risk that can be eliminated more easily than many other diet-associated health risks. This issue is particularly relevant to low socioeconomic groups, such as truck and taxi drivers and manual labourers, who, due to other lifestyle factors, already have an increased risk of coronary heart disease partly due to high prevalence of smoking and poor diet, including a high intake of I-TFA and metabolic syndrome. ${ }^{12}$
In 2012, EU countries, with the exception of Austria and Denmark, legally allow foods with the maximum concentration of I-TFA in the fat (ie, 60\%) to be sold without any notice as long as the food is unpackaged (as is the case for restaurants and fast food outlets). If the food is prepackaged, then the law requires the presence of I-TFA to be noted only by the term 'partially hydrogenated fat' in the list of ingredients. ${ }^{13}$ Most consumers do not appreciate the hazard concealed therein.

Societal pressure on food producers has undoubtedly resulted in a reduction in the population-level mean intake of I-TFA from 2005 to 2009, especially in Western EU countries. ${ }^{11}$

However, this study demonstrated that a high intake of I-TFA is still possible in Eastern EU countries. This problem will continue as long as popular foods with a high concentration of I-TFA are available. Even though 
Table 2 Amounts of industrial trans fatty acids (TFA) in a high-trans menu bought in the various countries in 2005

\begin{tabular}{|c|c|c|c|c|}
\hline & $\begin{array}{l}\text { Gram of TFA in a large } \\
\text { serving* of nuggets and } \\
\text { French fries }\end{array}$ & $\begin{array}{l}\text { Gram of TFA in } 100 \mathrm{~g} \\
\text { biscuits, cakes and } \\
\text { wafers }\end{array}$ & $\begin{array}{l}\text { Gram of TFA in } 100 \mathrm{~g} \\
\text { microwave popcorn }\end{array}$ & $\begin{array}{l}\text { Gram of TFA in a } \\
\text { high-trans menu }\end{array}$ \\
\hline Czech Republic 2005 & 16.8 & 15.3 & 11.6 & 43.7 \\
\hline Poland 2005 & 19.8 & 12.5 & 10.7 & 42.3 \\
\hline Hungary 2005 & 24.1 & 10.4 & 7.6 & 42.1 \\
\hline Bulgaria 2005 & 22.5 & 7.9 & 7.7 & 38.1 \\
\hline Romania 2005 & 15.3 & 3.5 & 11.8 & 30.6 \\
\hline France 2005 & 6.2 & 4.8 & 13.8 & 24.8 \\
\hline Germany 2005 & 4.9 & 6.9 & 12.4 & 24.2 \\
\hline Portugal 2005 & 4.0 & 5.5 & 13.9 & 23.4 \\
\hline Spain 2005 & 5.0 & 4.6 & 13.8 & 23.4 \\
\hline UK 2005 & 8.2 & 4.5 & 10.4 & 23.1 \\
\hline The Netherlands 2005 & 5.0 & 6.7 & 11.0 & 22.7 \\
\hline Austria 2005 & 4.2 & 8.4 & 9.4 & 22.0 \\
\hline Italy 2005 & 6.0 & 3.3 & 11.9 & 21.2 \\
\hline Sweden 2005 & 4.8 & 6.0 & 5.9 & 16.7 \\
\hline Finland 2005 & 5.9 & 4.6 & 0.1 & 10.6 \\
\hline Denmark 2001 & 10.0 & 17.0 & 10.0 & 37.0 \\
\hline Denmark 2005 & 0.3 & 0.3 & 0.3 & 0.9 \\
\hline
\end{tabular}

labelling foods with I-TFA contents may further reduce the mean intake of I-TFA, such labelling still allows the intake of high amounts of these fatty acids, first because fast food is not labelled and second because consumers might not pay attention to or understand the labelling. ${ }^{14} 15$

A further advantage of a legislative limit on I-TFA content is that it does not require the population to learn about the health risks of I-TFA or to pay attention to the labelling of food products. It is also much easier and cheaper to monitor the presence of I-TFA in foods than it is to monitor the actual intake of I-TFA in at-risk population subgroups.
In EU Austria and Denmark have shown that the health risk that a high intake of I-TFA causes, can be eliminated for the entire population without any noticeable side effects for consumers. This has the added advantage of creating a 'level playing field' for suppliers. All are equally challenged. All can profit from experience of successful and rapid adaptation as in Denmark. It remains to be investigated to what extent the difference of availability of I-TFA in popular foods between and Eastern and Western EU countries contributes to the much higher mortality of coronary heart disease in Eastern, than in Western EU countries (table 4 and figure 4$){ }^{16}$

Table 3 Amounts of industrial trans fatty acids (TFA) in various foods bought in three Eastern EU countries in 2005 and 2009 and in three Western EU countries in 2005 and 2009

\begin{tabular}{lllcl}
\hline & $\begin{array}{l}\text { Gram of TFA in a large } \\
\text { serving of nuggets and } \\
\text { French fries }\end{array}$ & $\begin{array}{l}\text { Gram of TFA in } \\
\mathbf{1 0 0} \mathbf{g} \text { biscuits/ } \\
\text { cakes/wafers }\end{array}$ & $\begin{array}{l}\text { Gram of TFA in 100 } \mathbf{~ g ~} \\
\text { microwave popcorn }\end{array}$ & $\begin{array}{l}\text { Gram of TFA in a } \\
\text { high-trans menu }\end{array}$ \\
\hline Hungary 2005 & 24.1 & 10.4 & 7.6 & 42.1 \\
Czech Republic 2005 & 14.1 & 15.3 & 11.6 & 41 \\
Poland 2005 & 19.1 & 12.5 & 6.7 & 38.3 \\
Hungary 2009 & $<1$ & 5.6 & 6.9 & 12.5 \\
Czech Republic 2009 & $<1$ & 2.3 & 16.8 & 19.1 \\
Poland 2009 & $<1$ & 6 & 7.6 & 13.6 \\
France 2005 & 62 & 4.8 & 13.8 & 24.8 \\
Germany 2005 & 53 & 6.9 & 12.4 & 24.6 \\
UK 2005 & 83 & 4.5 & 10.4 & 23.2 \\
France 2009 & $<1$ & $<1$ & $<1$ & $<1$ \\
Germany 2009 & $<1$ & $<1$ & $<1$ & $<1$ \\
UK 2009 & $<1$ & $<1$ & $<1$ & $<1$ \\
\hline
\end{tabular}


Table 4 Trends in ischaemic heart disease death rates, selected OECD countries, 1980-2006

\begin{tabular}{|c|c|c|c|}
\hline & Denmark & Hungary & OECD \\
\hline 1980 & 261.2 & 217 & 171.8 \\
\hline 1981 & 258.4 & 231.5 & 170.3 \\
\hline 1982 & 241.3 & 230.7 & 166.8 \\
\hline 1983 & 237.9 & 231 & 165.2 \\
\hline 1984 & 235.4 & 223.9 & 162.0 \\
\hline 1985 & 232.1 & 225 & 162.6 \\
\hline 1986 & 226.5 & 227.5 & 157.5 \\
\hline 1987 & 221.9 & 221.5 & 154.3 \\
\hline 1988 & 211.6 & 223.5 & 150.5 \\
\hline 1989 & 204.4 & 222.8 & 147.6 \\
\hline 1990 & 201.6 & 226.6 & 144.3 \\
\hline 1991 & 187.8 & 230.2 & 141.4 \\
\hline 1992 & 181.9 & 234.6 & 138.3 \\
\hline 1993 & 180.2 & 244.2 & 137.0 \\
\hline 1994 & 158.0 & 233.1 & 130.3 \\
\hline 1995 & 157.4 & 235.4 & 128.9 \\
\hline 1996 & 136.6 & 237.8 & 123.6 \\
\hline 1997 & 130.5 & 232.2 & 118.7 \\
\hline 1998 & 120.5 & 234.2 & 115.4 \\
\hline 1999 & 117.4 & 240.9 & 114.6 \\
\hline 2000 & 106.0 & 225.4 & 107.9 \\
\hline 2001 & 106.4 & 212.9 & 103.2 \\
\hline 2002 & 93.7 & 209.3 & 100.7 \\
\hline 2003 & 87.9 & 219.7 & 98.1 \\
\hline 2004 & 80.4 & 220.6 & 92.5 \\
\hline 2005 & 73.9 & 247.5 & 89.7 \\
\hline 2006 & 67.8 & 228.5 & 86.9 \\
\hline
\end{tabular}

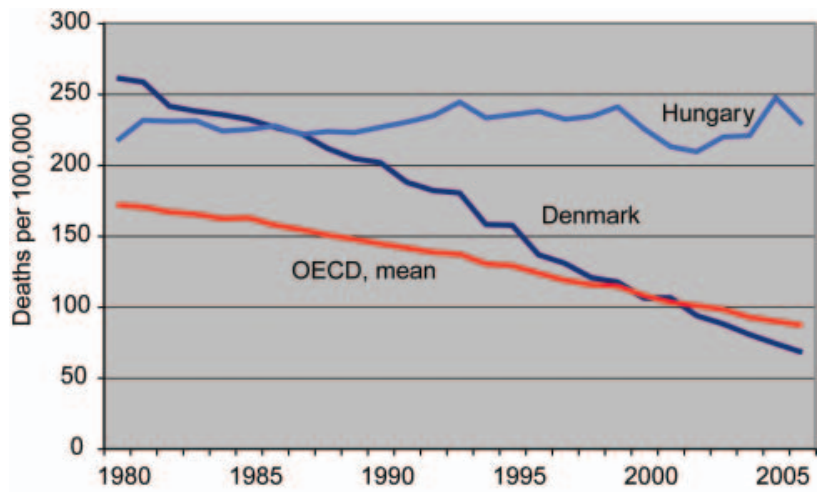

Figure 4 Trends in coronary heart disease death rates, selected OECD countries, 1980-2006. Source: OECD Health Data 2009. The raw mortality data are extracted from the WHO Mortality Database, and age-standardised to the 1980 OECD population. For 2006-2009 the yearly mortality for Hungary is 228, 215, 205 and 204. The corresponding values for Denmark and for OECD mean have not yet appeared in the OECD Health data 2011.
Acknowledgements We acknowledge the support from Jenny Vissings Foundation, University of Copenhagen and the Department of Clinical Biochemistry, Gentofte University Hospital.

Contributors SS and JD were both responsible for the concept design of the study, for collection of food items, registration and labelling. SS and JD produced the first draft of the study and SS, JD and AA were responsible for critical revision of the manuscript. SS is a guarantor for the study.

Funding University of Copenhagen, Jenny Vissings Foundation.

Competing interests None.

Provenance and peer review Not commissioned; externally peer reviewed.

Data sharing statement No additional data are available.

\section{REFERENCES}

1. Wahle KWJ, James WPT. Isomeric fatty acids and human health Eur J Clin Nutr 1993;47:828-39.

2. Mozaffarian D, Katan MB, Ascherio A, et al. Trans fatty acids and cardiovascular disease. N Engl J Med 2006;354:601-3.

3. World Health Organization. Population nutrient intake goals for preventing diet-related chronic diseases. 2003. http://www.who.int/ nutrition/topics/5_population_nutrient/en/index12.html (accessed May 2012).

4. Dietary Guidelines for Americans 2010. http://www.health.gov/ dietaryguidelines/dga2010/DietaryGuidelines2010.pdf (accessed May 2012).

5. Stender S, Dyerberg J. The influence of trans fatty acids on healthFourth edition. A report from the Danish Nutrition Council. 2003. http://www.meraadet.dk/default.asp?id=1347 (accessed May 2012).

6. van Poppel $\mathrm{G}$ on behalf of the TRANSFAIR Study Group. Intake of fatty acids in Western Europe: the TRANSFAIR Study. Lancet 1998;351:1099-106.

7. Stop Press: Commission drops Danish trans fat case. EU Food Law Weekly 2007;295(23 March)

8. Stender S, Dyerberg J, Bysted A, et al. A trans world journey. Atherosclr 2006;(Suppl 7):P47-52.

9. Stender S, Dyerberg J, Astrup A. High levels of industrially produced trans fat in popular fast foods. N Engl J Med 2006;354:1650-2.

10. Leth $\mathrm{T}$, Jensen HG, Mikkelsen AA, et al. The effect of the regulation on trans fatty acid content in Danish food. Atherosclr 2006;(Suppl 7):P53-6.

11. Katan MB. Regulation of trans fats: the Gap, the Polder, and McDonald's French fries. Atherosclr 2006;(Suppl 7):P69-71.

12. Gill PE, Wijk K. Case study of a healthy eating intervention for Swedish lorry drivers. Health Educ Res 2004;19:306-15.

13. Legislation relating to the level of industrially produced trans fatty acids in food in: the influence of trans fatty acids on health-Fourth edition. A report from the Danish Nutrition Council. 2003. http://www. meraadet.dk/default.asp?id=1347 (accessed May 2012).

14. Consumers find food labelling confusing: http://www.guardian.co.uk/ money/2009/may/07/food-drink-health-labels (accessed May 2012).

15. Borra S. Consumer perspectives on food labels. Am J Clin Nutr 2006;83:1235S.

16. OECD Health Data 2009: Statistics and Indicators. http://www.oecd. org/document/56/0,3746,en_2649_34631_12968734_1_1_1_1,00. html (accessed May 2012). 